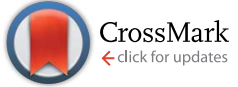

Cite this: RSC Adv., 2017, 7, 16049

Received 12th December 2016

Accepted 6th March 2017

DOI: $10.1039 / c 6 r a 28057 a$

rsc.li/rsc-advances

\title{
Effect of surface physicochemical properties on the flocculation behavior of Bacillus licheniformis $\uparrow$
}

\author{
Zhi Wang, ${ }^{\text {ab }}$ Zhen Chen, ${ }^{a}$ Lijie Yang, ${ }^{a}$ Fen Tan, ${ }^{a}$ Yuanpeng Wang, ${ }^{a}$ Qingbiao Li, ${ }^{a}$ \\ You-Im Chang, ${ }^{c}$ Chuan-Jian Zhong ${ }^{d}$ and Ning He*a
}

The flocculation behaviors of $B$. licheniformis CGMCC 2876 under different culture conditions were studied in this paper. In the non-bioflocculant producing process, the flocculability of $B$. licheniformis was enhanced with an increase of ionic strength from 0.001 to $0.3 \mathrm{M}$, and similar results were observed with the decrease of $\mathrm{pH}$ from 7 to 4 . The interfacial free energy between cells was $38.8 \mathrm{~mJ} \mathrm{~m}^{-2}$, suggesting the cells with hydrophilic surfaces repelled each other. In the bioflocculant producing process, extended DLVO theory was adopted to describe the flocculation behavior. The changes in the flocculation behavior of bacterial cells were primarily attributed to the hydrophobic attraction energy interaction between cells with the lowest value of $-104.1 \mathrm{~mJ} \mathrm{~m} \mathrm{~m}^{-2}$. Combined with scanning electron microscopy (SEM), transmission electron microscopy (TEM) and X-ray photoelectron spectroscopy analysis, the cell auto-flocculation of $B$. licheniformis was finally attributed to the hydrophobic polysaccharide secreted as a cell capsule, which led to an increased surface hydrophobicity, thus increasing the flocculation potential.

\section{Introduction}

Flocculation is seen as an easy, low-cost and eco-friendly process of cell separation, which does not require energy input. ${ }^{1}$ It has some advantages for industrial processes because of the simplicity of liquid/solid separation and the ease of cell mass retention in the reactor. ${ }^{2}$ In addition, some flocculation behaviors can play an important role beyond the cell separation process; such as in the case of brewing industry, where the failure of yeasts to flocculate can adversely affect beer flavor characteristics. ${ }^{3}$ As far as we know, flocculable cells are mainly reported with yeasts, which have been used for industrial purposes, for example continuous ethanol production from aggregated yeast and methane fermentation with an upflow anaerobic sludge-blanket reactor. ${ }^{4,5}$

As for bacteria, some studies about the flocculation ability have also been done, for instance, the photosynthetic bacterium, R. acidophila and Rhodovulum sp., and the activated

\footnotetext{
${ }^{a}$ Department of Chemical and Biochemical Engineering, College of Chemistry and Chemical Engineering, Xiamen University, Xiamen 361005, P. R. China. E-mail: hening@xmu.edu.cn; Fax: +86592 2184822; Tel: +86592 2189595

${ }^{b}$ Université de Toulouse, INSA, UPS, INP, LISBP, 135 Avenue de Rangueil, F-31077 Toulouse, France

'Department of Chemical and Material Engineering, Tunghai University, Taichung 40704, Taiwan

${ }^{d}$ Department of Chemistry, State University of New York at Binghamton, Binghamton, New York 13902, USA

$\dagger$ Electronic supplementary information (ESI) available: Fig. S1-S6 and Table S1. See DOI: $10.1039 / \mathrm{c} 6 \mathrm{ra} 28057 \mathrm{a}$
}

sludge flocs consisting of various bacteria. ${ }^{2,6-8}$ However, the flocculation characteristics and mechanism in bacteria cells has not been clearly explored.

The relationship between flocculence and cell hydrophobicity was found by Amory et al.9,10 Also the ionic strength, surface zeta potential and extracellular polymeric substances have been reported to be associated with the flocculation behaviors of Pseudomonas putida KT2442, Lactococcus lactis and some other marine bacteria. ${ }^{11-14}$ Correlations have been found between the microbial surface structures and the surface properties, for instance, the surface negative charges of Bacillus subtilis were attributed to phosphate groups, and the surface hydrophilicity of Escherichia coli was associated with high levels of $(\mathrm{C}-(\mathrm{O}, \mathrm{N}))$ and $(\mathrm{OH}-(\mathrm{C}-\mathrm{O}-\mathrm{C}))$ functional groups while the cell surface hydrophobicity was associated with $(\mathrm{C}-(\mathrm{C}, \mathrm{H}))$ functional groups. ${ }^{15-17}$

In our previous study, two different types of extracellular bioflocculants were determined in the culture of $B$. licheniformis, which have been proved their potential applications in sugar refinery industry. ${ }^{18,19}$ However, the separation of bacteria cells from the culture broth was hard due to the high viscosity of the solution. Thus, the cell flocculation behavior of B. licheniformis was evaluated in this research. The cell surface was characterized and the flocculation behavior of bacteria cells were discussed with extended DLVO (XDLVO) theory. This research will not only offer valuable results in bioflocculant production, but also provide important foundation for studies on the flocculation process of bacteria cells instead of yeast cells. 


\section{Materials and methods}

\subsection{Strain and culture conditions}

B. licheniformis, isolated in our laboratory and stored in the China General Microbiological Culture Collection Centre (CGMCC, Beijing, China) with the accession number 2876, was adopted in the present study. The compositions of the cultivation medium and cultivation conditions for B. licheniformis can be found in our previous paper. ${ }^{18}$ The cells were collected by centrifugation at $9000 \mathrm{rpm}$ for $20 \mathrm{~min}$ at given intervals and washed twice with physiological saline. Thereafter, the cell pellets were used in the analysis as follows.

\subsection{Microbial flocculation test}

In the present study, an index, $F$, was measured to describe the flocculating ability of $B$. licheniformis. ${ }^{20}$ The harvested cells were re-suspended in $\mathrm{NaCl}$ or $\mathrm{CaCl}_{2}$ electrolyte solutions with various concentrations of $0.001,0.003,0.01,0.03,0.1,0.3,1,3$ and $5 \mathrm{~mol}$ $\mathrm{L}^{-1}$. The optical density of the cell suspension was measured at $650 \mathrm{~nm}\left(A_{0}\right)$ using a UV-1800 spectrophotometer (Shimadzu). Thereafter, the $B$. licheniformis suspensions were centrifuged at $1000 \mathrm{rpm}$ for $2 \mathrm{~min}$ and the supernatant was measured again at $650 \mathrm{~nm}\left(A_{t}\right)$. Then, the $F$ value can be calculated as:

$$
F \%=\left(1-A_{t} / A_{0}\right) \times 100
$$

The effect of $\mathrm{pH}$ on flocculating ability of $B$. Licheniformis was examined using cell suspensions with $\mathrm{pH} 4-9$, which were adjusted by adding $1 \mathrm{~mol} \mathrm{~L}^{-1} \mathrm{HCl}$ or $\mathrm{NaOH}$.

\subsection{Surface characteristics}

2.3.1 Contact angle determination. The apparent advancing contact angle of the cells was measured using a contact angle analyzer. ${ }^{21}$ Briefly, the washed cells were captured on a cellulose acetate membrane filter (pore diameter $0.45 \mu \mathrm{m})$ by underpressure filtration. Homogeneous cellular layers were washed twice with ultrapure water and then placed in a Petri dish on $1 \%(\mathrm{w} / \mathrm{v})$ agar plate containing $10 \%(\mathrm{v} / \mathrm{v})$ glycerol to preserve a constant moisture content. The membranes were placed on glass sides and allowed to air dry for 30 to $90 \mathrm{~min}$. Contact angles was directly measured at $25{ }^{\circ} \mathrm{C}$, employing the sessile drop technique with a droplet of a specified polar or non-polar solvent. The polar and non-polar solvents used in the present study can be seen in Table S1. $\dagger$

2.3.2 Zeta potential measurements. The same suspension used for the flocculation test was also used for zeta potential measurements using a Nano-ZS and MPT-2 (Malvern, UK) to get information on the net charge of cells. In the present study, the zeta potentials of cell suspension were analyzed simultaneously as the function of culture time.

2.3.3 Cell surface thermodynamic evaluation. The surface tension of a substance i comprises the apolar (LW) component and the polar $(\mathrm{AB})$ component, which can be expressed as

$$
\gamma_{i}=\gamma_{i}^{\mathrm{LW}}+\gamma_{\mathrm{i}}^{\mathrm{AB}}
$$

where the $\gamma_{\mathrm{i}}^{\mathrm{AB}}$ component composed of the electron-acceptor surface tension parameter (designated as $\gamma_{i}^{+}$) and electrondonor parameter (designated as $\gamma_{\mathrm{i}}{ }^{-}$) can be defined as: ${ }^{22}$

$$
\gamma_{\mathrm{i}}^{\mathrm{AB}}=2 \sqrt{\gamma_{\mathrm{i}}^{+} \gamma_{\mathrm{i}}^{-}}
$$

The three unknown entities $\gamma_{\mathrm{B}}^{\mathrm{LW}},{\gamma_{\mathrm{B}}}^{+}$and $\gamma_{\mathrm{B}}{ }^{-}$of B. Licheniformis can be calculated by the Young's equation ${ }^{23}$

$$
(1+\cos \theta) \gamma_{\mathrm{L}}=2\left(\sqrt{\gamma_{\mathrm{B}}^{\mathrm{LW}} \gamma_{\mathrm{L}}^{\mathrm{LW}}}+\sqrt{\gamma_{\mathrm{B}}{ }^{+} \gamma_{\mathrm{L}}{ }^{-}}+\sqrt{\gamma_{\mathrm{B}}{ }^{-} \gamma_{\mathrm{L}}{ }^{+}}\right)
$$

where $\theta$ is the advancing contact angle between the cell surfaces and drops of liquid $\mathrm{L}$ and can be determined by the contact angle measurement method introduced above.

Then, the interfacial tension between cell surfaces and water, $\gamma_{\mathrm{BL}}$, can be calculated by eqn (5)-(7): $:^{24}$

$$
\begin{gathered}
\gamma_{\mathrm{BL}}=\gamma_{\mathrm{BL}}^{\mathrm{LW}}+\gamma_{\mathrm{BL}}^{\mathrm{AB}} \\
\gamma_{\mathrm{BL}}^{\mathrm{LW}}=\left(\sqrt{\gamma_{\mathrm{B}}^{\mathrm{LW}}}-\sqrt{\gamma_{\mathrm{L}}^{\mathrm{LW}}}\right)^{2} \\
\gamma_{\mathrm{BL}}^{\mathrm{AB}}=2\left(\sqrt{{\gamma_{\mathrm{B}}{ }^{+} \gamma_{\mathrm{B}}{ }^{-}}^{2}}+\sqrt{{\gamma_{\mathrm{L}}+\gamma_{\mathrm{L}}^{-}}^{-}}-\sqrt{\gamma_{\mathrm{B}}{ }^{+} \gamma_{\mathrm{L}}^{-}}-\sqrt{\gamma_{\mathrm{B}}{ }^{-} \gamma_{\mathrm{L}}^{+}}\right)
\end{gathered}
$$

Combined with the above equations, the free interaction energy between cells immersed in water is divided into two parts: the Lifshitz-van der Waals (LW) component and the acidbase $(\mathrm{AB})$ component. $^{25}$

$$
\Delta G_{\mathrm{BLB}}=\Delta G_{\mathrm{BLB}}^{\mathrm{LW}}+\Delta G_{\mathrm{BLB}}^{\mathrm{AB}}=-2 \gamma_{\mathrm{BL}}^{\mathrm{LW}}-2 \gamma_{\mathrm{BL}}^{\mathrm{AB}}
$$

2.3.4 X-ray photoelectron spectroscopy (XPS) analysis. In the present study, X-ray photoelectron spectroscopy analyses were performed as described by Amory et al., which had been improved and verified to ensure the repeatability and reliability. ${ }^{9}$ The harvested cell pellet was resuspended in $2 \mathrm{~mL}$ of deionized water, quickly immersed in liquid nitrogen, and freeze-dried. Subsequently, the obtained powder was mounted on standard studs by using double side adhesive tape. The measurements were carried out on a PHI QUANTUM 2000 instrument with a monochromatised microfocused Al X-ray source at $10 \mathrm{kV}$ and $20 \mathrm{~mA}$. Each analysis consisted of a wide survey scan (pass energy $187.85 \mathrm{eV}$, step size $0.8 \mathrm{eV}$ ) and a highresolution scan (pass energy $58.70 \mathrm{eV}$, step size $0.1 \mathrm{eV}$ ).

\subsection{Flocculating activity of the culture broth}

The modified method was used to determine the flocculating activity of the fermentation broth. ${ }^{26}$ Kaolin clay suspension was formed by suspending $0.2 \mathrm{~g}$ kaolin clay in $40 \mathrm{~mL}$ distilled water. After mixing, the suspension was diluted to $50 \mathrm{~mL}$ with $0.2 \mathrm{~g} \mathrm{~L}^{-1}$ of $\mathrm{CaCl}_{2}$ and certain amount of bioflocculant (fermentation broth). For each run of the flocculation test, the reaction was stirred at $300 \mathrm{rpm}$ for $5 \mathrm{~min}$ and then allowed to settle freely for $5 \mathrm{~min}$ at room temperature. By measuring the decrease in 
turbidity in the upper phase of the suspension, only $0.1 \mathrm{~mL}$ liquid in the top of the $50 \mathrm{~mL}$ suspension was transferred to micro cells and then its turbidity was measured. Flocculating activity can be expressed as the flocculating rate (FR), which is calculated by

$$
\mathrm{FR}(\%)=((A-B) / A) \times 100
$$

where $A$ and $B$ are the optical density values at $550 \mathrm{~nm}$ of the control and the sample, respectively.

\subsection{The classical DLVO and the XDLVO approach}

According to the classical DLVO theory, the total interaction energy $\left(V_{\mathrm{t}}\right)$ between two cells in a water can be regard as the sum of the Van der Waals attractive energy $\left(V_{\mathrm{d}}\right)$ and the electrostatic repulsive energy $\left(V_{\mathrm{e}}\right):^{27,28}$

$$
V_{\mathrm{t}}=V_{\mathrm{d}}+V_{\mathrm{e}}
$$

with

$$
\begin{gathered}
V_{\mathrm{d}}=-\frac{A_{\mathrm{BLB}} R}{12 H} \\
V_{\mathrm{e}}=\frac{\varepsilon R \phi_{\delta}^{2}}{2} \ln \{1+\exp (-\kappa H)\}
\end{gathered}
$$

where $A_{\mathrm{BLB}}$ is the Hamaker constant and its value can be determined from the equation as following: ${ }^{29}$

$$
A_{\mathrm{BLB}}=\left(\sqrt{A_{\mathrm{BB}}}-\sqrt{A_{\mathrm{LL}}}\right)^{2}=24 \pi l_{0}\left(\gamma_{\mathrm{B}}^{\mathrm{LW}}-\gamma_{\mathrm{L}}^{\mathrm{LW}}\right)^{2}
$$

where, the value of $\gamma_{\mathrm{B}}^{\mathrm{LW}}$ can be calculated from eqn $(4), l_{0}(\approx 0.157$ $\mathrm{nm}$ ) is the minimum equilibrium distance, ${ }^{30} \phi_{\delta}$ is the surface potential which is often represented by the zeta potential of the cell, $\kappa$ is the reciprocal of the double-layer thickness, $R$, with the assumed value of $2 \mu \mathrm{m}$ for $B$. Licheniformis, is the cell radius and $H$ represents the separation distance between two cells.

However, since the classical DLVO theory fails to predict the stabilities of very hydrophilic and very hydrophobic particle suspension, ${ }^{31}$ hence the acid-base interaction $\left(V_{\mathrm{ab}}\right)$ is introduced into the following XDLVO theory: ${ }^{32}$

$$
V_{\mathrm{t}}^{\prime}=V_{\mathrm{d}}+V_{\mathrm{e}}+V_{\mathrm{ab}}
$$

with

$$
V_{\mathrm{ab}}=\pi R \lambda \Delta G_{l_{0}}^{\mathrm{AB}} \exp \left(\frac{l_{0}-H}{\lambda}\right)
$$

where $\Delta G_{l_{0}}^{\mathrm{AB}}$ is defined in eqn (8) and the value of the decay length $\lambda$ which is controlled both by the particle size and the ionic strength of the suspensions varies from $0.6 \mathrm{~nm}$ to $13 \mathrm{~nm} \cdot .^{30,33}$

\section{Results and discussion}

\subsection{DLVO approach to cellular interactions in non- bioflocculant producing process}

3.1.1 Effects of ionic strength on the flocculability of $B$. licheniformis. Fig. 1(a) showed that the zeta potential of $B$.
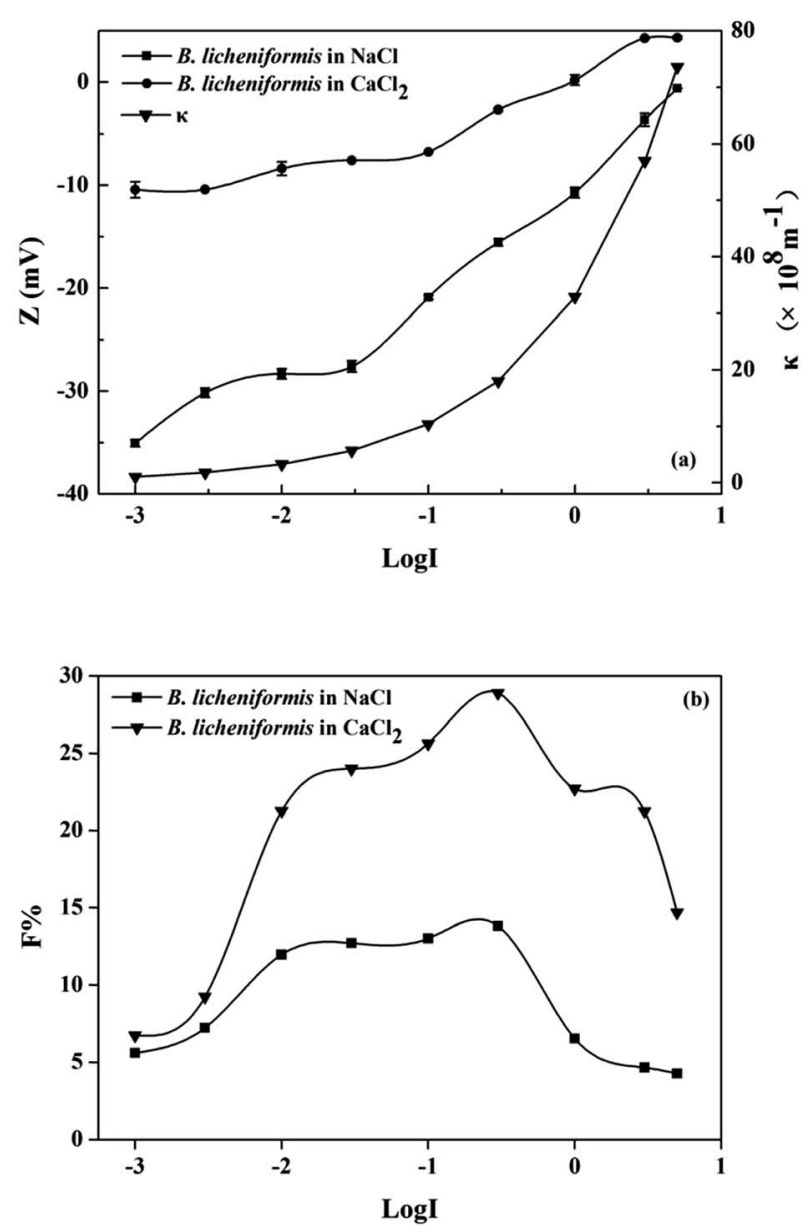

Fig. 1 Effect of ionic strength on the (a) zeta potential, $\kappa$ and (b) flocculability of $B$. licheniformis.

licheniformis cultured in non-bioflocculant producing medium, increased from $-35.1 \mathrm{mV}$ to zero below $(-0.6 \mathrm{mV})$ with an increase of $\mathrm{NaCl}$ concentration from 0.001 to $5 \mathrm{M}$. This was caused by the compression of the diffuse double layer $\left(\kappa^{-1}\right)$. Zeta potentials in $\mathrm{CaCl}_{2}$ electrolyte solution were lower than those in $\mathrm{NaCl}$ electrolyte solutions at the same ionic strength, indicating that $\mathrm{Ca}^{2+}$ has a stronger compression ability on $\kappa^{-1}$ than $\mathrm{Na}^{+}$. The flocculability of $B$. licheniformis in various ionic strength were shown in Fig. 1(b). Both in $\mathrm{NaCl}$ and $\mathrm{CaCl}_{2}$ solutions, the flocculability, expressed as $F$, increased with the increase of ionic strength from 0.001 to $0.3 \mathrm{M}$, then decreased sharply with a further increase in ionic strength over $0.3 \mathrm{M}$. The peak value of $F(<30)$ suggested the poor flocculability of $B$. licheniformis in non-bioflocculant producing process.

The variations of potential energy between $B$. licheniformis cells at different ionic strengths were described with classical DLVO theory (Fig. S1 $\dagger$ ). With the increase of electrolyte concentration from 0.003 to $0.3 \mathrm{M}$, the diffuse double layer was compressed and zeta potential decreased, hence the contribution of electrostatic repulsive energy to the total interaction energy became less and the maximum energy barrier dropped from 2188 to $116 \mathrm{kT}$. However, the flocculation performance of B. Licheniformis was still poor because even the lowest potential 
barrier (116 kT) is still ten times higher than the critical flocculation energy barrier (10 kT), beyond which the hydrophobic colloidal particles were always difficult to flocculate with each other. $^{\mathbf{1 0 , 2 8}}$ In spite of this, the energy barriers between cells would be well predicted with the classical DLVO theory at an ionic strength from 0.001 to $0.3 \mathrm{M}$. But at higher ionic strength, cell flocculability deviated from the predicted curve as an additional repulsive hydration force might play an important role between cells. ${ }^{10}$

3.1.2 Effects of pH on the flocculability of $\mathrm{B}$. licheniformis. The zeta potentials and flocculability of $B$. licheniformis as a function of $\mathrm{pH}$ were shown in Fig. 2(a). Zeta potential decreased with an increase in $\mathrm{pH}$ from 4 to 7 . This was attributed to the adsorption of $\mathrm{H}^{+}$, a potential-determining ion. ${ }^{34}$ Similar changes were found with $F$ because the electrostatic repulsive energy was reduced with the increased cellular zeta potential according to the classical DLVO theory. ${ }^{25}$ The minimum value of $F$ was 12.1 at $\mathrm{pH}$ 7. Both zeta potential and flocculability of the cells increased with the increase of $\mathrm{pH}$ from 7 to 9 afterwards. Similar phenomenon was reported by Lin et al. that the adsorption of Pseudomonas putida on minerals varied with $\mathrm{pH}$ values, which was probably related to the changing of surface properties. ${ }^{35}$

Using DLVO theory, the energy barriers at different $\mathrm{pH}$ were described in Fig. 2(b). The effects of ionic strength on the DLVO energy barrier $V_{\mathrm{t}}$ and flocculability $F$ were much stronger than that of $\mathrm{pH}$. Under different $\mathrm{pH}$ conditions, the contribution of $V_{\mathrm{d}}$ to the total interaction energy of $B$. licheniformis was invariant, while that of $V_{\mathrm{e}}$ was changing (Fig. S2 $\dagger$ ). Thus, this difference led to different $F$ at different $\mathrm{pH}$ values. As shown in eqn (11), the effective Hamaker constant $\left(A_{\mathrm{BLB}}\right)$ was the main factor that governs $V_{\mathrm{a}}$. The apolar component of the B. licheniformis surface tension $\left(30.4 \mathrm{~mJ} \mathrm{~m}^{-2}\right)$, which controls the value of $A_{\mathrm{BLB}}$ (eqn (13)), showed no much difference with that of water $\left(21.8 \mathrm{~mJ} \mathrm{~m}^{-2}\right)$. Thus $A_{\mathrm{BLB}}$ was $1.32 \times 10^{-21} \mathrm{~J}$, even lower than $10^{-20} \mathrm{~J}$ which was mostly used in previous bacterial studies. $^{36,37}$ Consequently, the contribution of $V_{\mathrm{d}}$ can be neglected and the cellular suspensions kept stable in our study. There has been report that the attractions between cells were primarily caused by Van der Waals attractive energy which were typically independence of $\mathrm{pH}$ and ionic strength based on DLVO theory. ${ }^{12}$
Table 1 Contact angles, surface tension and surface energy of $B$. licheniformis obtained in the present experiments ${ }^{a}$

\begin{tabular}{llllll}
\hline \multicolumn{2}{l}{$\begin{array}{l}\text { Contact } \\
\text { angle }\left(^{\circ}\right)\end{array}$} & \multicolumn{4}{l}{$\begin{array}{l}\text { Surface tension and surface free energy of } B . \\
\text { licheniformis and their components }\left(\mathrm{mJ} \mathrm{m}^{-2}\right)\end{array}$} \\
\hline$\theta^{\mathrm{Wa}}$ & \multirow{2}{*}{45.6} & B. licheniformis & $\gamma_{\mathrm{B}}$ & $\gamma_{\mathrm{B}}^{\mathrm{LW}}$ & $\gamma_{\mathrm{B}}^{\mathrm{AB}}$ \\
& & & 30.8 & 30.4 & 0.40 \\
$\theta^{\mathrm{Fo}}$ & 55.0 & B. licheniformis-water & $\gamma_{\mathrm{BL}}$ & $\gamma_{\mathrm{BL}}^{\mathrm{LW}}$ & $\gamma_{\mathrm{BL}}^{\mathrm{AB}}$ \\
& & & -19.4 & 0.71 & -20.1 \\
$\theta^{\mathrm{Br}}$ & 48.4 & B. licheniformis-B. & $\Delta G_{\mathrm{BLB}}$ & $\Delta G_{\mathrm{BLB}}^{\mathrm{LW}}$ & $\Delta G_{\mathrm{BLB}}^{\mathrm{AB}}$ \\
& & licheniformis & 38.8 & -1.42 & 40.2
\end{tabular}

${ }^{a}$ Wa, water; Fo, formamide; $\mathrm{Br}, \alpha$-bromonaphthalene.

\subsection{Contact angles and surface thermodynamics of $B$. licheniformis}

In principle, the contact angle ranged from 0 to $180^{\circ}$, and the cell surfaces with water contact angle lower than $90^{\circ}$ could be designated as hydrophilic. ${ }^{38}$ Also, the hydrophilic cells were those with $\Delta G_{\mathrm{BLB}}>0$, whereas hydrophobic cells were those with $\Delta G_{\mathrm{BLB}}<0 .{ }^{39}$ The surface free energies of $B$. licheniformis were presented in Table 1 . Both the water contact angle and interfacial free energy indicated that the cell surface was hydrophilic. The surface free energy connoted the repulsion between cells. Generally, the Lifshitz-van der Waals component $\left(\Delta G_{\mathrm{BLB}}^{\mathrm{LW}}\right)$ is negative, responsible for cell attraction, but $\Delta G_{\mathrm{BLB}}^{\mathrm{AB}}$ can be either repulsive or attractive. ${ }^{40}$ As for B. licheniformis, the value of $\Delta G_{\mathrm{BLB}}^{\mathrm{LW}}$ was $-1.42 \mathrm{~mJ} \mathrm{~m}^{-2}$ because of similar apolar (LW) surface tension component to that of water. The repulsive acid-base component $\left(\Delta G_{\mathrm{BLB}}^{\mathrm{AB}}\right)$ of $40.2 \mathrm{~mJ} \mathrm{~m}^{-2}$ dominated in the cell to cell interaction energy. Therefore, the suspension of $B$. Licheniformis had a flocculability of no more than $30 \%$. This could be the primary cause for the poor flocculating ability of the bacterial cells.

\subsection{Flocculation characterization of $B$. licheniformis in the bioflocculant producing process}

3.3.1 The contact angles and zeta potentials. Time courses of zeta potentials of the cells along with flocculating activity of the fermentation broth and glucose consumption were shown in Fig. 3(a). The measured temporal variations of microbial
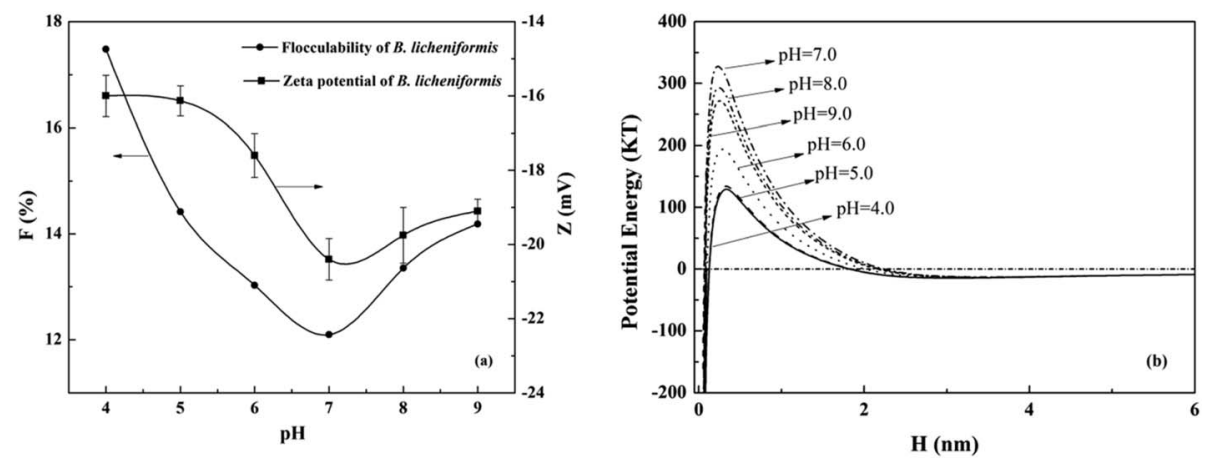

Fig. 2 Effects of $\mathrm{pH}$ on the (a) zeta potential, flocculability and (b) DLVO potential energy of B. licheniformis in $0.3 \mathrm{M} \mathrm{NaCl}$ solution. 

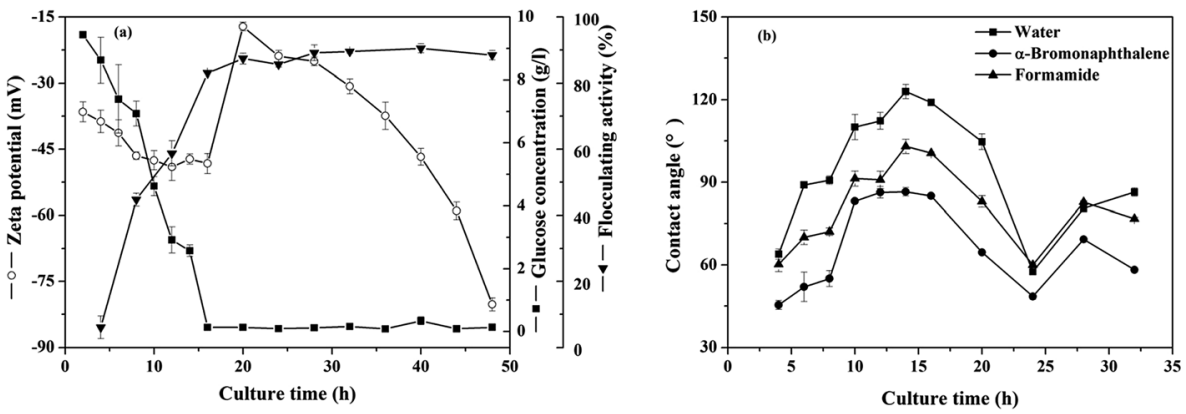

Fig. 3 Temporal variations of (a) the zeta potentials, residual glucose concentration, flocculating activity and (b) contact angles on bacterial lawns for $B$. licheniformis during the bioflocculant producing process

concentration of $B$. licheniformis during the bioflocculant producing process indicated that the exponential growth phase ended at the end of the 24th hour of cultivation time (Fig. S3†). Glucose was consumed rapidly and the flocculating activity of the culture broth increased to $83 \%$ in the first 16 hours, meanwhile zeta potentials decreased from -36.5 to $-48.3 \mathrm{mV}$ in the first 16 hours, then jumped to $-17.2 \mathrm{mV}$ near the end of the exponential growth phase period before decreasing. As shown in Fig. 3(b), the water contact angle raised from 63.9 to $119.0^{\circ}$ at the 14 th hour, which indicated that the cell surface was starting to change from hydrophilic to hydrophobic in the first 14 hours and thus the cells would change from repulsive to attractive with each other. This result was further explained with the cellular surface free energy later.

3.3.2 Quantification of the surface thermodynamics. It was already proved that the cellular surface thermodynamics changed at different growth phase, such as the decrease in hydrophobicity of Azospirillum brasilens during growth and the changing of the interfacial free energy from negative to positive for Ralstonia eutropha in its entire growth phase. ${ }^{41,42}$ As shown in Fig. 4(a)-(d), the cellular surface tension and free energy of $B$. licheniformis were calculated. Van Oss had previously suggested that $\gamma_{\mathrm{B}}^{\mathrm{LW}}$ values for most hydrophilic biological material surfaces was $40 \mathrm{~mJ} \mathrm{~m}^{-2}$ with minor variability. ${ }^{40}$ As shown in Fig. 4(b), a $\gamma_{\mathrm{B}}^{\mathrm{LW}}$ value of $30 \mathrm{~mJ} \mathrm{~m}^{-2}$ was obtained only at the first 8 hours of the growth phase, which was comparable to that reported by Van Oss. Then, $\gamma_{\mathrm{B}}^{\mathrm{LW}}$ decreased to nearly $10 \mathrm{~mJ} \mathrm{~m}^{-2}$ when bioflocculant was produced at the stationary phase, which indicated that the hydrophilic parts of the cellular surfaces decreased. It is worth noting that the polar (AB) component gave almost no contribution to the cell surface tension because the cell surface belonged to the electron donor with no electronacceptor capacity (Fig. 4(a)). Thus, the surface tension was the same as the apolar (LW) component. These style substances
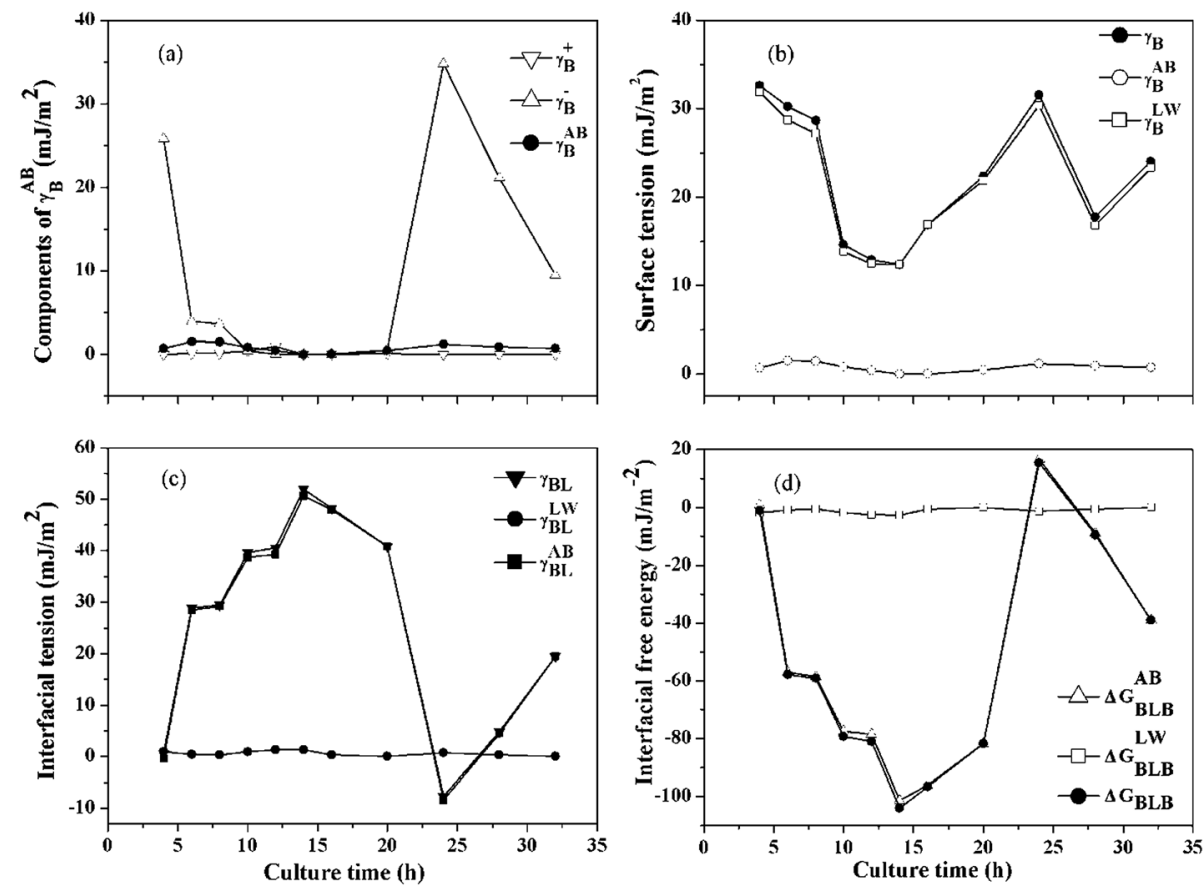

Fig. 4 Surface thermodynamics parameters of $B$. licheniformis during the bioflocculant producing process: (a) components of $\gamma_{B}^{A B}$, (b) surface tension of bacteria, (c) interfacial tension between bacteria and water, (d) interfacial free energy between bacteria immersed in water. 
were always described as monopoles, with a strong $\gamma_{\mathrm{B}}{ }^{+}$or a strong $\gamma_{\mathrm{B}}{ }^{-}$parameter, but these parameters, in the absence of a surface tension parameter of the opposite sign, do not contribute to the energy of flocculation. ${ }^{22}$ Even so, the $\gamma_{\mathrm{B}}{ }^{-}$ exhibited a significantly change compared with $\gamma_{\mathrm{B}}{ }^{+}$, reflecting the variation of cell surface structure, i.e., the functional groups such as $\mathrm{RCOH}$ and $\mathrm{RCOOH}$ favor $\gamma_{\mathrm{B}}{ }^{-}$, while the functional groups such as $-\mathrm{CH}=\mathrm{CH}-$ and $>\mathrm{C}=\mathrm{CH}_{2}-$ weaken $\gamma_{\mathrm{B}}{ }^{-} \cdot{ }^{43}$

In contrast with the polar $(\mathrm{AB})$ component $\left(\gamma_{\mathrm{BL}}^{\mathrm{LW}}\right)$, the acidbase $(\mathrm{AB})$ component $\left(\gamma_{\mathrm{BL}}^{\mathrm{AB}}\right)$ could be negative or positive as shown in Fig. 4(c). With $\gamma_{\mathrm{BL}}^{\mathrm{AB}}>0, \Delta G_{\mathrm{BLB}}^{\mathrm{AB}}<0$, the cells immersed in water attracted each other and the attractive energy belonged to the hydrophobic attraction energy, even electrical surface charges were presented on the cellular surfaces and vice versa. ${ }^{\mathbf{4 4}}$ As shown in Fig. 4(d), the contribution of $\Delta G_{\mathrm{BLB}}^{\mathrm{LW}}$ could be neglected because of the great changing in $\Delta G_{\mathrm{BLB}}^{\mathrm{AB}}$. So the values of $\Delta G_{\mathrm{BLB}}$ were the same as that of $\Delta G_{\mathrm{BLB}}^{\mathrm{AB}}$, and the maximum change of $\Delta G_{\mathrm{BLB}}$ occurred at the 14th hour, which indicated that the hydrophobic parts of cell surface raised and cell flocculation occurred at the exponential growth phase. The cellular surfaces started to switch from hydrophilic to hydrophobic and the role of the hydrophobic attraction energy became more important gradually.

\subsection{The XDLVO approach to cellular interactions in the bioflocculant producing process}

The images of Fig. 5 showed the most cell aggregation at the 16th hour during growth. This was caused by the rise of hydrophobicity of cell surface. From TEM images, capsules were found on the cell surface during bioflocculant production, which contributed to the surface hydrophobic properties.
Based on classical DLVO theory, the energy barriers were always higher than $1500 \mathrm{kT}$ (Fig. S4 $\dagger$ ) during the whole process of bioflocculant production. This was in contrast to the phenomena observed by using scanning electron microscope. Nevertheless, based on the XDLVO theory, where the acid-base energy $\left(V_{\mathrm{ab}}\right)$ was included in eqn (14), the energy barriers became lower from the 6th to 14th hour, resulting in easier flocculation behavior. Cell flocculation was more obvious at an energy barrier of $6.4 \mathrm{kT}$ at the 8th hour than at an energy barrier of $16.6 \mathrm{kT}$ at the 6th hour (higher than the critical energy barrier of flocculation $10 \mathrm{kT}$ ). ${ }^{10}$ Similarly, the energy barriers vanished after 10 hours of cultivation, demonstrating that the cells could easily flocculate. These were in quite agreement with the experimental results of $\Delta G_{\mathrm{BLB}}$, which proved that XDLVO theory was more suitable to describe the flocculation behavior of $B$. licheniformis cells during the process of bioflocculant production.

In classical DLVO theory, the bacteria cells were assumed perfectly smooth surfaces, ${ }^{\mathbf{4 5}}$ which was quite a different case with B. licheniformis CGMCC 2876 when capsule was formed in the bioflocculant producing process. On the other hand, XDLVO equation, including an additional acid-base interaction item depending on the acid-base surface energy component, could well elucidate the surface characteristics and flocculability of $B$. licheniformis cells in the bioflocculant producing process. The item of the acid-base interactions in the equation exerted a significant decrease to the total energy barrier, which was caused by the negative acid-base interactions from the 6th to 14th hour of cultivation (Fig. S5 $\dagger$ ). Based on the surface thermodynamics of $B$. licheniformis, the cells were strong electron donors, thus had the acid-base surface energy component, ${ }^{\mathbf{4}}$ which inevitably generated negative and attractive acid-base interactions between B. licheniformis.

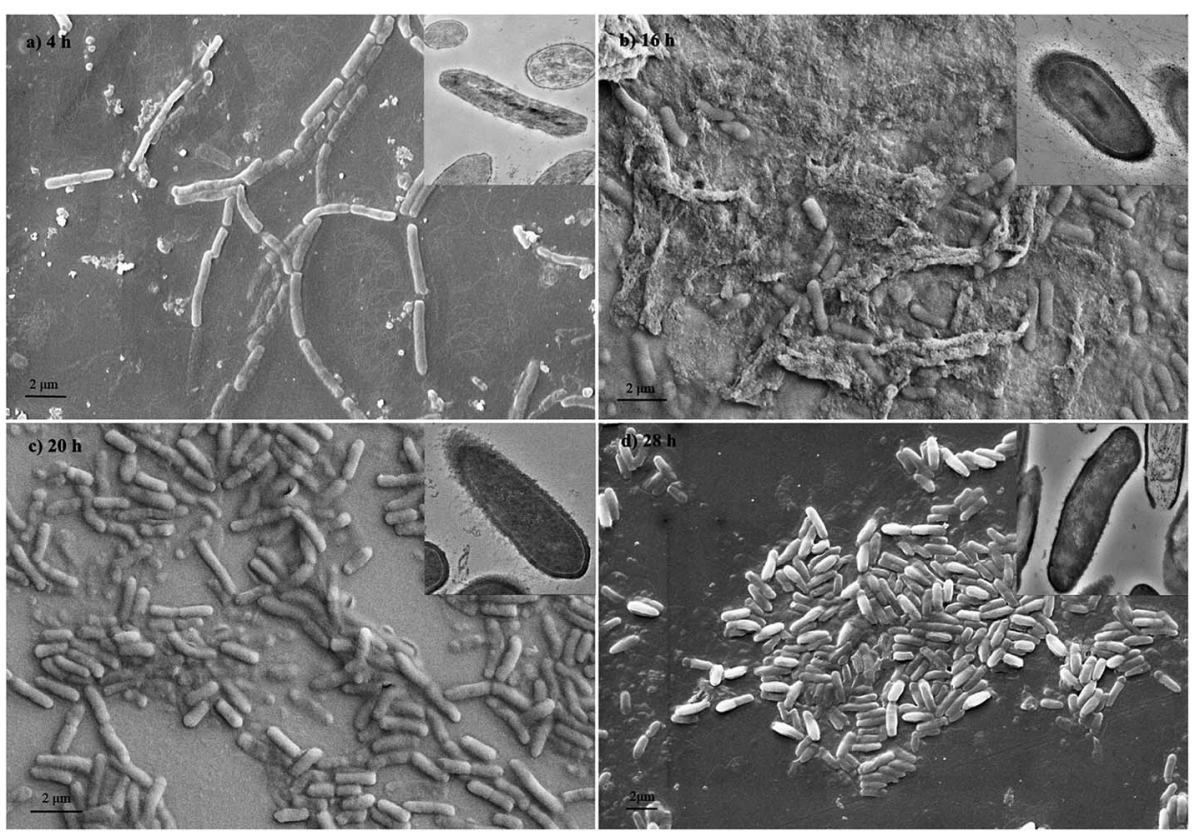

Fig. 5 Scanning electron micrographs and transmission electron microscopy (in the top right corner) photos of $B$. Licheniformis at different growth phase. 


\subsection{Relationship between the flocculation behavior and cell surface compositions}

XPS could provide an elemental analysis of the outmost layer of the bacterial cell with a depth $2-5 \mathrm{~nm}$ owing to inelastic scattering of the electrons in the sample. ${ }^{47}$ Since Baddiley et al. reported the use of XPS analysis for the study of bacteria in 1973, there have been many applications of XPS to microorganism. ${ }^{48-50}$ Three equations were adopted in the present analysis:

$$
\begin{gathered}
N / C=0.279\left(C_{\mathrm{Pr}} / C\right) \\
O / C=0.325\left(C_{\mathrm{Pr}} / C\right)+0.833\left(C_{\mathrm{Ps}} / C\right) \\
1=C_{\mathrm{Pr}} / C+C_{\mathrm{Ps}} / C+C_{\mathrm{CH}} / C
\end{gathered}
$$

where $C_{\mathrm{Pr}}, C_{\mathrm{Ps}}$, and $C_{\mathrm{CH}}$ are the atomic concentrations of carbon present in peptides, polysaccharides, and hydrocarbon-like products, respectively. $\mathrm{N} / \mathrm{C}$ and $\mathrm{O} / \mathrm{C}$ are atomic concentration ratios of oxygen and nitrogen, respectively, with respect to carbon.

Results showed that the percentage of proteins on cell surface fell from $56.0 \%$ at the 4 th hour to $19.3 \%$ at the 14 th hour. Meanwhile, the percentages of polysaccharides and lipids rose to $46.2 \%$ and $34.5 \%$, respectively, which may contribute to the increased hydrophobicity of cell surface (Fig. S6 $\dagger$ ). Then, the increase in the content of proteins from the 14th hour to the 16th hour, especially near the latter time of the 16th hour of cultivation, gave rise to the reduction of water contact angle and the increase of $\Delta G_{\mathrm{BLB}}$ slightly as shown in Fig. 3 and 4, respectively. Further calculation suggested that the increase of protein produced a linear decrease of water contact angle and increase of interfacial free energy in exponential phase. For the increase of polysaccharide, did the opposite (Fig. S7†). Lipids always had been reported to be hydrophobic. ${ }^{24,51}$

As the extracellular polymeric substance is multicomponent soft materials with microstructures that are not fixed in time, the bacterial surface hydrophobicity and flocculation behaviors are always different in the period of fermentation. ${ }^{41,52}$ Sugars were all rather hydrophilic and quite soluble in water, nonetheless, these in the form of polymers could became more hydrophobic for the structure. ${ }^{24}$ It was because of the polysaccharides produced on the surface with large size and intertwined shape that the bacteria cells had hydrophobic properties in water. ${ }^{26}$ Similarly, extracellular polysaccharides of Aulacoseira granulata were found to be hydrophobic and have an promotional role on bacterial flocculation. ${ }^{53}$ The amazing ability of Azospirillum to interact with a fairly wide range of host plants was studied and found to be associated with the carbohydrate components of bacteria surface. ${ }^{54}$ In addition, it was found that E. coli initial adhesion to solid substrates was dependent on molecular interactions caused by lipopolysaccharides. ${ }^{55}$ Proteins can comprise hydrophilic and/or hydrophobic amino acids in any proportion..$^{24}$ In our present study, the cell surface hydrophobic property increased along with the decrease of protein. However, different phenomenon was found in Azospirillum brasilens. ${ }^{41}$ In general, both saturated chains and
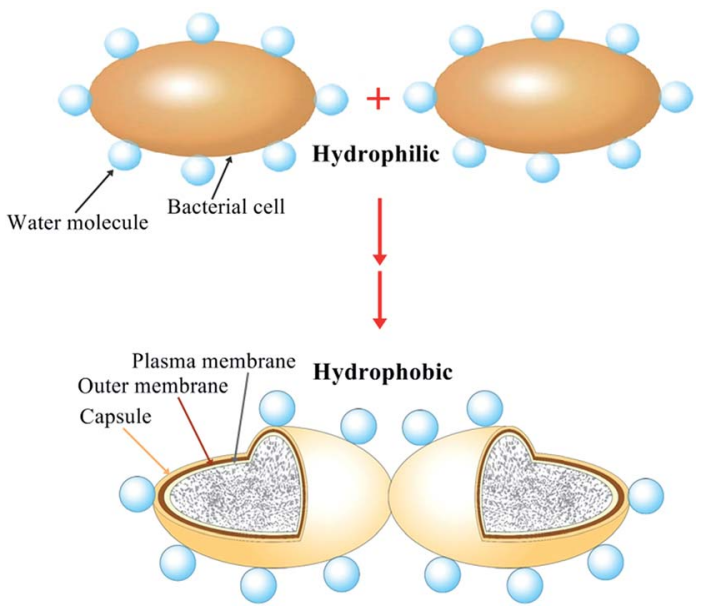

Fig. 6 Flocculation model of B. Licheniformis (not to scale).

unsaturated chains attracted each other in water, which would generate a hydrophobic energy of attraction. ${ }^{24}$ The concentrations of lipid on two hydrophilic bacteria surfaces studied by Rouxhet et al. were all lower than $15.0 \% .^{51}$ However, B. licheniformis had a higher proportion of lipid on surface during bioflocculant producing process, which facilitated the cellular flocculation.

\subsection{Hypothesis of the flocculation mechanism}

Base on the characterization of surface physicochemical properties, XDLVO analysis and cell surface changing during the process of bioflocculant production, the flocculation model of $B$. licheniformis was hypothesized in Fig. 6. Initially, the bacteria, surrounded by water molecule, had hydrophilic surface and its suspension was stable. However, with the secretion of bioflocculant, comprising hydrophobic polysaccharides, a capsule was formed around the cell surface. Then, the value of the interfacial free energy between cells, especially for the acid-base (AB) component, was decreased, suggesting the increase of hydrophobicity of cell surface. Meanwhile, the value of the acid-base energy was and water molecules were rejected with the strengthening of cell surface hydrophobicity. Thus, the bacteria became attracted and finally flocculated with each other.

\section{Conclusions}

All these results about the experimentally surface physicochemical characteristics and XDLVO theory could well bridge the micro-scale structures with the flocculation behavior of $B$. licheniformis. It is proved that variation in surface composition is the essential cause of hydrophobic (or hydrophilic) property of the cellular surface, and the properties of cell surface can in turn affect the flocculation behavior of the cells themselves indeed, which will allow us to apply their flocculation behavior in cultivation and harvesting of cells, achieving energetic and economic viability. 


\section{Acknowledgements}

This work was financially supported by the National Natural Science Foundation of China $(51378444,21676221)$, Xiamen Southern Oceanographic Center (15GYY024NF03) and the University of Science and Technology in Fujian Province in the cooperative major project $(2015 \mathrm{H} 6004)$, the program for New Century Exellent Talents of Education Ministry of China (ncet13-0501).

\section{References}

1 E. V. Soares, J. Appl. Microbiol., 2010, 110, 1-18.

2 M. Watanabe, K. Sasaki, Y. Nakashimada, T. Kakizono, N. Noparatnaraporn and N. Nishio, Appl. Microbiol. Biotechnol., 1998, 50, 682-691.

3 K. J. Verstrepen, G. Derdelinckx, H. Verachtert and F. R. Delvaux, Appl. Microbiol. Biotechnol., 2003, 61, 197-205.

4 G. Lettinga, A. F. M. V. Velsen, S. W. Hobma, W. D. Zeeuw and A. Klapwijk, Biotechnol. Bioeng., 1980, 22, 699-734.

5 F. H. White and A. D. Portno, J. Inst. Brew., 1978, 84, 228-230. 6 T. T. More, J. S. Yadav, S. Yan, R. D. Tyagi and R. Y. Surampalli, J. Environ. Manage., 2014, 144, 1-25.

7 B.-M. Wilén, B. Jin and P. Lant, Water Res., 2003, 37, 21272139.

8 G. P. Sheng, H. Q. Yu and Z. B. Yue, Appl. Microbiol. Biotechnol., 2005, 69, 216-222.

9 D. E. Amory and P. G. Rouxhet, J. Inst. Brew., 1988, 94, 79-84. 10 Y.-I. Chang and P.-K. Chang, Colloids Surf., A, 2002, 211, 6777.

11 N. Mangwani, S. K. Shukla, S. Kumari, S. Das and T. S. Rao, RSC Adv., 2016, 6, 57540-57551.

12 N. I. Abu-Lail and T. A. Camesano, Biomacromolecules, 2003, 4, 1000-1012.

13 A. J. D. Kerchove and M. Elimelech, Langmuir, 2005, 21, 6462-6472.

14 T. Nomura, H. Narahara, H. Tokumoto and Y. Konishi, Adv. Powder Technol., 2009, 20, 537-541.

15 F. Ahimou, C. J. P. Boonaert, Y. Adriaensen, P. Jacques, P. Thonart, M. Paquot and P. G. Rouxhet, J. Colloid Interface Sci., 2007, 309, 49-55.

16 F. Hamadi, H. Latrache, H. Zahir, A. Elghmari, M. Timinouni and M. Ellouali, Braz. J. Microbiol., 2008, 39, 10-15.

17 P. G. Rouxhet and M. J. Genet, Surf. Interface Anal., 2011, 43, 1453-1470.

18 Y. Xiong, Y. Wang, Y. Yu, Q. Li, H. Wang, R. Chen and N. He, Appl. Environ. Microbiol., 2010, 76, 2778-2782.

19 X. Zhuang, Y. Wang, Q. Li, S. Yan and N. He, Biotechnol. Bioprocess Eng., 2012, 17, 1041-1047.

20 X. Liu, G. Sheng and H. Yu, Environ. Sci. Technol., 2007, 41, 4620-4625.

21 H. J. Busscher, A. H. Weerkamp, H. C. V. D. Mei, A. W. J. V. Pelt, H. P. D. Jong and A. J. Arends, Appl. Environ. Microbiol., 1984, 48, 980-983.

22 C. J. V. Oss, R. J. Good and M. K. Chaudhury, Langmuir, 1988, 4, 884-891.

23 T. Young, Philos. Trans. R. Soc. London, 1805, 95, 65-87.
24 C. J. V. Oss, Colloids Surf., B, 1995, 5, 91-110.

25 A. Vilinska and K. H. Rao, Miner. Metall. Process., 2011, 28, 151-158.

26 Z. Wang, L. Shen, X. Zhuang, J. Shi, Y. Wang, N. He and Y.-I. Chang, Ind. Eng. Chem. Res., 2015, 54, 2894-2901.

27 B. V. Derjaguin and L. D. Landau, Acta Physicochim. URSS, 1941, 14, 633-662.

28 E. J. W. Verwey and J. T. G. Overbeck, Theory of the stability of lyophobic colloids, Elsevier Academic press, Amsterdam, 1948.

29 D. G. Brown and P. R. Jaffe, Environ. Sci. Technol., 2006, 40, 195-201.

30 C. J. V. Oss, M. K. Chaudhury and R. J. Good, Chem. Rev., 1988, 88, 927-941.

31 H. Yotsumoto and R. H. Yoon, J. Colloid Interface Sci., 1993, 157, 426-433.

32 S. Song and S. Lu, J. Colloid Interface Sci., 1994, 166, 35-42. 33 Y. Zeng, S. Grandner, C. L. P. Oliveira, A. F. Thünemann, O. Paris, J. S. Pedersen, S. H. L. Klapp and R. von Klitzing, Soft Matter, 2011, 7, 10899-10909.

34 K. Doymus, Turk. J. Chem., 2007, 31, 589-597.

35 D. Lin, W. Ma, Z. Jin, Y. Wang, Q. Huang and P. Cai, Colloids Surf., B, 2016, 138, 10-16.

36 D. G. Brown, Environ. Sci. Technol., 2006, 40, 195-201.

37 M. J. Gross, O. Albinger, D. G. Jewett, B. E. Logan, R. C. Bales and R. G. Arnold, Water Res., 1995, 29, 1151-1158.

38 R. A. Gittens, L. Scheideler, F. Rupp, S. L. Hyzy, J. GeisGerstorfer, Z. Schwartz and B. D. Boyan, Acta Biomater., 2014, 10, 2907-2918.

39 C. J. V. Oss, Cell Biophys., 1989, 14, 1-16.

40 C. J. V. Oss, Colloids Surf., A, 1993, 78, 1-49.

41 Y. F. Dufrgne and P. G. Rouxhet, Can. J. Microbiol., 1996, 42, 548-556.

42 X. M. Liu, G. P. Sheng, J. Wang and H. Q. Yu, Appl. Microbiol. Biotechnol., 2008, 79, 187-194.

43 K. A. Strevett and G. Chen, Res. Microbiol., 2003, 154, 329-335. 44 C. J. van Oss, J. Mol. Neurosci., 2003, 16, 177-190.

45 M. Hermansson, Colloids Surf., B, 1999, 14, 105-119.

46 A. Ozkan and H. Berberoglu, Colloids Surf., B, 2013, 112, 302-309.

47 P. G. Rouxhet, N. Mozes, P. B. Dengis, Y. F. Dufrene, P. A. Gerin and M. J. Genet, Colloids Surf., B, 1994, 2, 347-369.

48 J. Baddiley, I. C. Hancock and P. M. A. Sherwood, Nature, 1973, 243, 43-45.

49 P. B. Dengis, P. A. Gerin and P. G. Rouxhet, Colloids Surf., B, 1995, 4, 199-211.

50 H. C. V. D. Mei, J. D. Vries and H. J. Busscher, Surf. Sci. Rep., 2000, 39, 1-24.

51 C. J. P. Boonaert and P. G. Rouxhet, Appl. Environ. Microbiol., 2000, 66, 2548-2554.

52 J. M. Arroyo, D. Olmos, B. Orgaz, C. H. Puga, C. San José and J. González-Benito, RSC Adv., 2014, 4, 51451-51458.

53 A. A. H. Vieira, P. I. C. Ortolano, D. Giroldo, M. J. D. Oliveira, T. B. Bittar, A. T. Lombardi and A. L. Sartori, Limnol. Oceanogr., 2008, 53, 1887-1899.

54 I. M. Skvortsov and V. V. Ignatov, FEMS Microbiol. Lett., 1998, 165, 223-229.

55 Q. Lu, J. Wang, A. Faghihnejad, H. Zeng and Y. Liu, Soft Matter, 2011, 7, 9366-9379. 